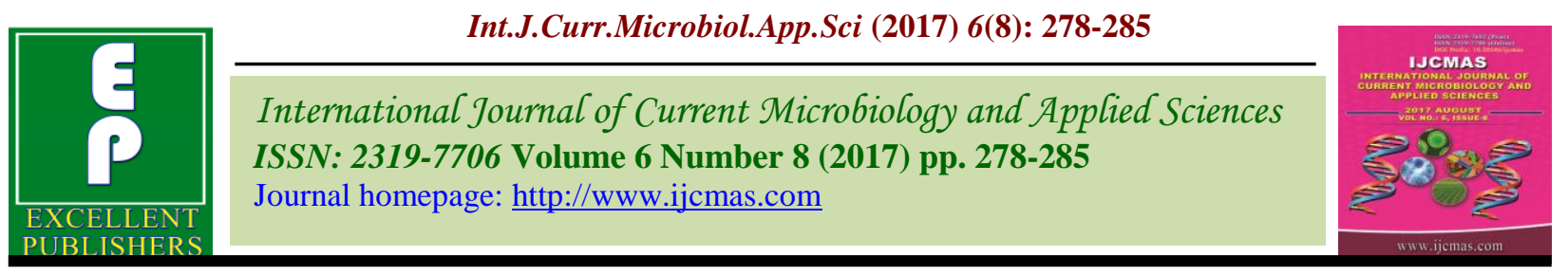

Original Research Article

https://doi.org/10.20546/ijcmas.2017.608.037

\title{
Isolation of High-Yielding Mutants through EMS-Induced Mutagenesis in Linseed (Linum usitatissimum L.)
}

\author{
Mohammad Rafeeq M. Kulmi*, Suma C. Mogali, Kusmadevi S. Patil, and T.M. Leelavathi \\ Department of Genetic and Plant Breeding, University of Agricultural Sciences, \\ Dharwad - 580005 (Karnataka), India \\ *Corresponding author
}

A B S T R A C T

Keywords

Genetic

variability,

Induced mutation,

Linum

usitatissimum.

Article Info

Accepted:

04 June 2017

Available Online:

10 August 2017
Induced mutations have proven flexible, workable and ready to use on any crop. In addition, it is a low-cost technology that has the ability to address current challenges in agriculture. The breeding of new mutant varieties with a higher yield potential will be the driving force to meet the challenges of the $21^{\text {st }}$ century. Highyielding mutants were isolated from the $\mathrm{M}_{3}$ progeny of linseed varieties Indira Alsi and NL-115 treated with 0.1, 0.2, 0.3, 0.4 and 0.5 \% EMS. Data on various quantitative traits, such as plant height, number of primary branches per plant, number of secondary branches per plant, number of capsules per plant, number of seeds per capsules, 1000-seed weight (g), seed yield (g) per plant, were recorded for 10 superior mutants in the $\mathrm{M}_{3}$ generation. The mutants were morphologically quite distinct, as compared to the control and to each other. The most notable change was increase in number of secondary branches and capsule numbers of these mutants, giving them high yield as compared to control. Mean performance of different quantitative traits was significantly better among the mutants as compared to the control, with a few exceptions.

\section{Introduction}

Linseed (Linumus itatissimum L., $2 \mathrm{n}=30$ ) is an important oilseed and fibre crop belonging to family Linaceae, which consists of 13 genera and 300 species. It is a self pollinated and annual crop used by humans for at least nine millennium and possibly for as long as 30 millennium (van Zeist and Bakker-Heeres, 1975; Zohary and Hopf, 2000). Genesar and Morris (2003) suggested that the crop has been originated from the Indian sub-continent as the greatest genetic diversity of this crop present in this area. Linseed (Linumus itatissimum L.) is an important oilseed crop in the world. Every part of the linseed plant has its own commercial value. As a nutritional point of view linseed contain, a mixture of fatty acids i.e., alpha-linolenic acid (ALA) and linolenic acid (LA), ALA and Linoleic acid constitutes $57 \%$ and $16.0 \%$ of total fatty acids respectively in flax, making it the richest source of ALA. Animal studies have shown that ALA reduce hypertension, cholesterol and triglyceride level and responsible for preventing colon carcinogenesis in mice and it has been reported as reducing the breast 
cancer risk in mice (Ganorkar and Jain, 2013). The linseed crop maintained its increasing trend in productivity while the area registered the declining trend, resulting in stagnant production. Linseed is the most neglected oilseed crop of developing countries grown on marginal land with poor management. Poor yield of linseed crop is attributed to non-availability of improved cultivars to suit the diverse agro climatic conditions. Hence, development of high yielding cultivars becomes the top priority to overcome the poor yield levels. To break the yield plateau, genetic diversity is the prerequisite for genetic improvement of any crops. To widen the genetic base, the use of mutagens has been proved to be beneficial since long Muller (1927) and Stadler (1928) in Drosophila Melanogaster and Barley, respectively.

Attempts for linseed improvement have been made earlier through various approaches including induced mutations (Sinha et al., 1981). However, still there remains a wide scope of improvement in linseed in almost all aspects including yield. While genetic engineering is becoming a popular tool for crop improvement induced mutations still carries its relevance in terms of simpler infrastructural needs and its applicability. Mutations have been instrumental in crop improvement since they were proved to be inducible. Since then, mutations are being employed directly or indirectly for improving various traits of plants. More than 1500 direct mutants have been released as varieties in the last century. In addition to this about 700 mutants have been used in crosses to breed improved varieties (Laguda, 2004).

\section{Materials and Methods}

The present experiment was conducted in two seasons viz., rabi, 2013-14 and 2014-15 at Main Agricultural Research Station
(MARS), University of Agricultural Sciences, Dharwad. The experimental material was developed by involving two promising varieties viz. Indira Alsi and NL115.

Two varietal seeds were treated with chemical mutagen, ethylmethane sulfonate (EMS) at five different doses from $0.1 \%$ EMS to $0.5 \%$ EMS respectively. The EMS solution was prepared in $0.1 \mathrm{M}$ phosphate buffer ( $\mathrm{pH}-7.0)$. The pre hydrated seeds (8 hours) were soaked in EMS solution of respective concentrations for 18 hours and later washed in running water to remove chemical residue and shade dried before sowing.

The treated seeds of both the varieties were sown in the field during rabi 2012-2013 along with respective control to raise $\mathrm{M}_{1}$ generation. All the recommended agronomic and plant protection practices were followed to raise the crop. The surviving plants were harvested separately to raise $\mathrm{M}_{2}$ generation.

The two EMS treated varieties were advanced to $M_{2}$ generation. However, no progenies were advanced from 0.3 per cent EMS treatment in Indira Alsi and 0.5 per cent EMS treatment in NL-115, respectively as no desirable progenies were observed. Approximately $200 \quad \mathrm{M}_{2}$ plants of each treatment and 80 untreated plants of both the variety were maintained in the field. At the time of harvest, observations were recorded on around 20 randomly selected plants from treated and 15 plants from untreated parents for yield and yield related characters. A total of 105 mutants were selected from $\mathrm{M}_{2}$ generation and were raised as plant to progeny rows along with respective untreated parents, which consisted of 40 plants selected from mutants of Indira Alsi and 65 plants selected from mutants of NL115. The experiment was laid out in two sets of augmented randomized block. 
Induced quantitative variability with respect to the following 10 characters were studied: number of days to $50 \%$ flowering, plant height $(\mathrm{cm})$, Days to maturity, Plant height at maturity $(\mathrm{cm})$, number of primary branches, number of secondary branches, number of capsules, Number of seeds per capsule seed yield (g), Test weight (g) Oil Content (\%) and Fatty acid composition. Variances in the $M_{2}$ and $M_{3}$ generations for these different quantitative characters, based on both the experimental and the control data, were statistically analyzed as suggested by Panse and Sukhatme (1978) and Singh and Chaudhary (1985).

The data recorded were processed with the help of Ms-excel and Windostat version 8.1 available at Department of Genetics and Plant Breeding, University of Agricultural Sciences, Dharwad. The statistical parameters viz., range, mean, variance, standard error, coefficient of variation and other variability parameters were computed for all the traits in $\mathrm{M}_{2}$ generation and $\mathrm{M}_{3}$ generation.

\section{Results and Discussion}

The details of mutants isolated in $\mathrm{M}_{3}$ generation and of their parents (controls) are given in tables 3 and 4 . Since yield per plant is the most desirable character, certain mutants which were distinctly much superior to the others with regard to the seed yield per plant were selected in $\mathrm{M}_{3}$ generation.

While in control population, traits under study did not exhibit much of variability, it was too large in the mutants. Increase in variability following mutagenic treatments was also reported by Ahmad et al., (2014), Akbar et al., (2003), Ioan (2001), Jagadeesan et al., (2008). Selection for number secondary branches, number of capsules per plant and seed yield per plant in $\mathrm{M}_{3}$ generation was found to be effective in mutants, as is evident from the manifold increase in the values of the genotypic coefficient of variation, heritability and genetic advance as compared to the control, indicating that these traits can be transmitted to the future generations and further improvement of these quantitative traits is possible in subsequent generations. In order to know the breeding utility of this variability and selection value of various quantitative traits, it is essential to determine various components and heritable proportion of variability (Gottschalk and Kaul, 1980). Johnson et al., (1955) suggested that heritability estimates coupled with the estimated genetic advance are more helpful than the heritability values alone. This is because the heritability estimates are subjected to certain estimation errors (Lin et al., 1979) and genotype - environment interaction (Kaul and Garg, 1979). Frey (1969) reported that mutagen derived variability for quantitative characters in crop plants is heritable and that the response to selection is good. Delayed selection is preferred as deleterious mutations are generally eliminated in early generations.

Superior mutants selected for seed yield, Mutant No.57-3 isolated from NL-115 treated with $0.2 \%$ EMS has recorded highest yield of $15.99 \mathrm{~g}$ per plant compared to $3.16 \mathrm{~g}$ in control (NL-115), this considerable increase in yield is owing to increase in number of secondary branches (75), number of capsules per plant (230) and enhanced test weight of $10.25 \mathrm{~g}$. Likewise in Mutant No.79-4 (0.3\% EMS) which recorded 12.10 $\mathrm{g}$ the increase in yield can be attributed to increase in number of secondary branches (73), number of capsules per plant (215) and mainly test weight $(14.63 \mathrm{~g})$ which is 1.54 times the control mean $(9.45 \mathrm{~g})$ (Table 2). 
Table.1 Mean, range and genetic variability parameters for growth and yield parameters in mutant families $\left(\mathrm{M}_{3}\right)$ of Indira Alsi

\begin{tabular}{|c|c|c|c|c|c|c|c|c|c|c|}
\hline $\begin{array}{l}\text { Sl. } \\
\text { No. }\end{array}$ & Characters & $\begin{array}{c}\text { Parent mean } \\
\text { (Indira Alsi) }\end{array}$ & Mean & Min & $\operatorname{Max}$ & GCV & PCV & $\mathbf{h}^{2}(\mathrm{bs})$ & GA & GAM \\
\hline 3 & Plant height & 48.04 & 48.21 & 30.50 & 63.50 & 15.05 & 15.51 & 94.21 & 14.48 & 30.10 \\
\hline 5 & $\begin{array}{l}\text { No. of } \\
\text { Secondary } \\
\text { branches per } \\
\text { plant }\end{array}$ & 27.11 & 35.14 & 9.00 & 82.50 & 39.00 & 41.76 & 87.23 & 26.42 & 75.04 \\
\hline 6 & $\begin{array}{l}\text { No. of capsules } \\
\text { per plant }\end{array}$ & 56.07 & 70.10 & 14.67 & 187.50 & 40.44 & 43.50 & 86.40 & 54.22 & 77.43 \\
\hline 9 & Test weight(g) & 10.46 & 8.93 & 5.29 & 14.18 & 12.36 & 24.97 & 24.50 & 1.12 & 12.60 \\
\hline 10 & Oil content \% & 38.92 & 39.85 & 36.80 & 43.04 & 1.390 & 1.906 & 53.19 & 0.83 & 2.08 \\
\hline
\end{tabular}

Selection intensity at 5\% 
Table.2 Mean, range and genetic variability parameters for growth and yield parameters in mutant families $\left(\mathrm{M}_{3}\right)$ of NL-115

\begin{tabular}{|c|c|c|c|c|c|c|c|c|c|c|}
\hline $\begin{array}{l}\text { Sl. } \\
\text { No. }\end{array}$ & Characters & $\begin{array}{l}\text { Parent means } \\
\text { NL-115 }\end{array}$ & Mean & Min & Max & GCV & PCV & $\begin{array}{c}\mathbf{h}^{2} \\
(\mathbf{b s}) \\
\end{array}$ & GA & GAM \\
\hline 1 & Days to $50 \%$ flowering & 45.20 & 48.91 & 35.00 & 55.00 & 5.98 & 6.13 & 95.09 & 5.87 & 12.01 \\
\hline 2 & Days to maturity & 104.00 & 106.95 & 100.00 & 114.00 & 1.78 & 1.896 & 87.84 & 3.67 & 3.43 \\
\hline 3 & Plant height & 46.64 & 50.35 & 24.00 & 63.50 & 11.60 & 12.55 & 77.74 & 10.12 & 20.10 \\
\hline 4 & $\begin{array}{l}\text { No. of Primary branches per } \\
\text { plant }\end{array}$ & 4.37 & 7.14 & 3.00 & 19.50 & 41.21 & 46.51 & 78.52 & 5.37 & 75.23 \\
\hline 5 & $\begin{array}{l}\text { No. of Secondary branches } \\
\text { per plant }\end{array}$ & 23.25 & 39.43 & 10.00 & 103.00 & 53.14 & 55.77 & 90.80 & 41.13 & 104.32 \\
\hline 6 & No. of capsules per plant & 56.01 & 82.69 & 18.00 & 259.67 & 62.41 & 64.75 & 92.90 & 107.09 & 129.52 \\
\hline 7 & No. of seeds per capsule & 6.00 & 4.97 & 3.00 & 8.00 & 12.71 & 19.83 & 41.08 & 0.83 & 16.78 \\
\hline 8 & Yield per plant (g) & 2.16 & 2.52 & 0.47 & 6.95 & 57.06 & 61.3 & 86.6 & 2.75 & 109.42 \\
\hline 9 & Test weight & 9.45 & 9.03 & 4.97 & 15.01 & 22.86 & 24.53 & 86.84 & 3.96 & 43.88 \\
\hline 10 & Oil content \% & 39.74 & 40.13 & 37.60 & 45.12 & 2.11 & 2.77 & 57.74 & 1.32 & 3.30 \\
\hline
\end{tabular}

Selection intensity at 5\% 
Table.3 Superior mutants for seed yield derived from Indira Alsi in $\mathrm{M}_{3}$ generation

\begin{tabular}{|c|c|c|c|c|c|c|c|c|c|}
\hline Mutants & $\begin{array}{c}\text { Days to } \\
50 \% \\
\text { flowering }\end{array}$ & $\begin{array}{l}\text { Days to } \\
\text { maturity }\end{array}$ & $\begin{array}{l}\text { Plant } \\
\text { height }\end{array}$ & $\begin{array}{c}\text { Number of } \\
\text { primary } \\
\text { branches/plant }\end{array}$ & $\begin{array}{c}\text { Number of } \\
\text { secondary } \\
\text { branches/plant }\end{array}$ & $\begin{array}{c}\text { Number } \\
\text { of } \\
\text { capsules/ } \\
\text { plant }\end{array}$ & $\begin{array}{c}\text { Number of } \\
\text { seeds/capsule }\end{array}$ & $\begin{array}{c}\text { Seed } \\
\text { yield } \\
\text { /plant }\end{array}$ & $\begin{array}{c}\text { Test } \\
\text { weight }\end{array}$ \\
\hline $102-6$ & 50 & 107 & 49 & 8 & 40 & 215 & 6 & 10.25 & 8.63 \\
\hline $53-3$ & 48 & 105 & 36 & 9 & 56 & 225 & 5 & 10.12 & 8.92 \\
\hline $102-4$ & 51 & 107 & 67 & 10 & 52 & 108 & 10 & 7.36 & 7.14 \\
\hline $10-1$ & 41 & 105 & 37 & 12 & 53 & 135 & 6 & 6.73 & 7.69 \\
\hline $91-2$ & 51 & 108 & 52 & 12 & 72 & 122 & 5 & 6.27 & 8.18 \\
\hline Indira Alsi Mean & 45.4 & 104 & 48.04 & 5.2 & 27.11 & 56.07 & 6.6 & 2.21 & 10.46 \\
\hline CD at $5 \%$ & 2.09 & 3.045 & 4.815 & 2.063 & 14.084 & 30.107 & 1.826 & 1.655 & 5.192 \\
\hline
\end{tabular}

Table.4 Superior mutants for seed yield derived from NL-115 in $\mathrm{M}_{3}$ generation

\begin{tabular}{|c|c|c|c|c|c|c|c|c|c|}
\hline Mutants & $\begin{array}{c}\text { Days to } \\
\mathbf{5 0 \%} \\
\text { flowering }\end{array}$ & $\begin{array}{c}\text { Days to } \\
\text { maturity }\end{array}$ & $\begin{array}{c}\text { Plant } \\
\text { height }\end{array}$ & $\begin{array}{c}\text { Number of } \\
\text { primary } \\
\text { branches/plant }\end{array}$ & $\begin{array}{c}\text { Number of } \\
\text { secondary } \\
\text { branches/plant }\end{array}$ & $\begin{array}{c}\text { Number } \\
\text { of } \\
\text { capsules/ } \\
\text { plant }\end{array}$ & $\begin{array}{c}\text { Number of } \\
\text { seeds/capsule }\end{array}$ & $\begin{array}{c}\text { Seed } \\
\text { yield } \\
\text { /plant }\end{array}$ & $\begin{array}{c}\text { Test } \\
\text { weight }\end{array}$ \\
\hline $57-3$ & 51 & 108 & 62 & 5 & 75 & 230 & 6 & $\mathbf{1 5 . 9 9}$ & 10.25 \\
\hline $79-4$ & 51 & 108 & 53 & 9 & 73 & 215 & 5 & $\mathbf{1 2 . 1 0}$ & 14.63 \\
\hline $60-4$ & 49 & 105 & 52 & 12 & 103 & 438 & 5 & $\mathbf{1 0 . 6 6}$ & 14.39 \\
\hline $26-3$ & 51 & 105 & 59 & 19 & 209 & 325 & 4 & $\mathbf{1 0 . 0 4}$ & 8.64 \\
\hline $56-3$ & 51 & 110 & 67 & 9 & 52 & 256 & 4 & $\mathbf{9 . 0 6}$ & 9.24 \\
\hline $\begin{array}{c}\text { NL-115 } \\
\text { Mean }\end{array}$ & 46.4 & 105 & 46.23 & 4.42 & 19.7 & 62.54 & 5.83 & 1.64 & 10.46 \\
\hline $\begin{array}{c}\text { CD at } \\
5 \%\end{array}$ & $\mathbf{1 . 7 8}$ & $\mathbf{1 . 8 9 5}$ & $\mathbf{7 . 9 8 9}$ & $\mathbf{4 . 1 2 1}$ & $\mathbf{1 7 . 8 7 1}$ & $\mathbf{2 2 . 3 4}$ & $\mathbf{2 . 0 2 7}$ & $\mathbf{1 . 2 2 3}$ & 8.21 \\
\hline
\end{tabular}


Similarly in other high yielding mutants viz., Mutant No. 60-4 (0.2\% EMS), 26-3 (0.1\% EMS) and 56-3 (0.2\% EMS) the amplified yield can be owed to improvement in yield attributing traits like number of secondary branches, number of capsules per plant and test weight.

In Indira Alsi, high yielding mutant 102-6 derived from $0.5 \%$ EMS treatment for its considerable increase in number of secondary branches and number of capsules per plant. Other high yielding mutants viz., 53-3 (0.2\% EMS), $102-4(0.5 \%$ EMS $), 10-1(0.1 \%$ EMS $)$ and $91-2(0.4 \%$ EMS) recorded increased yield owing to increase in yield attributing traits such as number of primary branches, number of secondary branches, number of capsules, Number of seeds per capsule seed yield (g), Test weight (g) (Table 1).

Yield being a polygenic character, the yield advantage obtained might be due to the favorable gene mutation at more than one loci. Similar results were obtained by Badere and Choudary (2004) where they isolated high yielding mutants with increased number of seeds per plant. According to them the increase in number of seeds was due to enhancement in the yield contributing characters such as, capsules per plant and seeds per capsule. The improved mutants need to be evaluated for stability and if found consistently superior, it can be released as a variety.

In conclusion, the results reported in this study demonstrated the usefulness and the effective potential of the induced mutational approaches in genetic improvement of the linseed for recovering superior mutant plant types having high seed yield, besides higher oil content. As linseed is a nutritious oil seed in human diet, its high yielding mutants coupled with higher oil content would assume substantial economic importance.
The isolated mutants possessed a desirable plant architecture associated with high yield and slightly higher seed oil content than the control. They can be evaluated in future generations and after multi-location trials may be released as new varieties. Thus the genetic variability induced by chemical mutagens can effectively be exploited for the improvement of linseed in terms of yield and nutritional balance.

\section{References}

Ahmad, R., Danish Ibrar, M., Yasin Mirza., Talat Mahmood, Mubashir Ahmad Khan., Muhammad Shahid Iqbal and Munir Ahmad. 2014. Genetic variability, heritability and genetic advance in some genotypes of linseed (Linumus itatissimum L). J. Agric. Res., 52(1): 43-52.

Akbar, M., Mahmood, T., Anwar, M., Ali, M., Shafiq, M. and Salim, J. 2003. Linseed improvement through genetic variability, correlation and path coefficient analysis. Int. J. Agric. Biol., 5: 303-305.

Badere, R.S. and Chaudhary, A.D. 2004. Induced mutation in linseed (Linumus itatissimum L.). Indian J. Genet. Pl. Breed., 64(2): 159-160.

Frey, K.J. 1969. Release of mutagen induced genetic variability in oats by out crossing, Japan J. Genet., 44: 396-403.

Ganorkar, P.M. and Jain, R.K. 2013. Flaxseed - a nutritional punch. Int. Food Res. J., 20(2): 519-525

Genser, A.D. and N.D. Morris. 2003. History of cultivation and uses of flaxseed. In Flax- The genus Linum [A.D. Muir and N. D. Westcott, eds]. London, pp. 1-21.

Gottschalk, W., M.L.H. Kaul. 1980. Gene ecological investigation in Pisum mutants, Part II, Comparative performance in Germany and Northern 
India, Theoretical and Appl. Genetics, 56: 71-79.

Ioan. 2001. Variability of some morphological traits and seed yield obtained by oil linseed genotypes at the Agricultural Research Station of Podu Iloaiei. Cercetari Agronomice in Molodova, 34: 71-76.

Jagadeesan, S., Kandasamy, G., Manivannan, N. and Muralidharan, V. 2008. Mean and variability studies in M1 and M2 generations of sunflower (Helianthus annuus L.). Helia., 31(49): 71-78.

Johnson, H.W., H.F. Robinson, R.F. Comstock. 1955. Estimates of genetic and environmental variability in soybean, Agron. J., 47: 314-318.

Kaul M.L.H., Garg. R. 1979. Population performance and genetic parameters of some promising pea lines. Pisum Newslett., 11: 15-16.

Laguda, P.J.L. 2004. REDBIO20O4 MAS, Vol. 4(3).

Lin, C.Y., I. Pevzner, G.W. Friars. 1979. Experimental investigation of errors of heritability estimates in index selection, Canadian J. Genet., 21: 303-308.
Muller, H.J. 1927. Artificial transmutation of the gene. Sci., 66: 84-87.

Panse, V.G. and Sukhatme, P.V. 1957. Statistical Methods for Agricultural Workers, ICAR Publications, New Delhi, pp. 270-274.

Singh, R.K. and Chaudhary, B.D. 1985. Biometrical methods in quantitative genetic analysis. Kalyani Publishers, New Delhi, pp. 39-78.

Sinha, S.K., Srivastava, S., Prasad, R.R. and Haider, Z.A. 1981. Improvement for oil content in Linseed by Irradiation. Indian J. Agric. Sci., 51(11): 776.

Stadler, L.J. 1928. Mutations in barley induced by $\mathrm{x}$-ray and radium. Sci., 68 : 186.

Van Zeist, W. and Bakker-Heeres, J.A.H. 1975. Evidence for linseed cultivation before 6000 BC. J. Archaeol. Sci., 2: 215-219.

Zohary, D. and Hopf, M. 2000. Domestication of plants in the old world: the origin and spread of cultivated plants in West Asia, Europe and the Nile Valley. Oxford University Press, Oxford, pp. 240-246.

\section{How to cite this article:}

Mohammad Rafeeq M. Kulmi, Suma C. Mogali, Kusmadevi S. Patil, and T.M. Leelavathi. 2017. Isolation of High-Yielding Mutants through EMS-Induced Mutagenesis in Linseed (Linum usitatissimum L.). Int.J.Curr.Microbiol.App.Sci. 6(8): 278-285. doi: https://doi.org/10.20546/ijcmas.2017.608.037 